\title{
ADAPTING SCHOOL SITING TO SCHOOL CHOICE AND COMPACT CITY POLICIES
}

\author{
PIA WESTFORD \\ Swedish National Board of Housing, Building and Planning.
}

\begin{abstract}
Many countries have adopted school reforms that give parents an extended opportunity to choose schools for their children. State schools are expected to compete. This gives rise to questions of how to organise and site state schools. In addition, many local and central governments have adopted policies of compact and mixed-use urban development. The aim of this paper is to examine how local governments adapt school planning and the siting of schools to the school reforms, in combination with urban development policies. The paper is based on examination of strategic documents and semistructured interviews with 17 strategic officials in five fast growing municipalities in Sweden. The result shows that local governments are adapting to school choice by planning for much larger schools in combination with compact urban development. A location criterion for schools for children aged 13-15 is in attractive, central parts of cities. The official location criterion for schools for children aged 6-12 is in proximity to the local need and in consideration of younger children's limited reach. However, densification developments lead to difficulties in siting schools where they are needed. Areas in the periphery and sometimes socially deprived neighbourhoods are avoided. Moreover, planners use subjective assessments of closeness, while objective proximity measurements are outdated. Proximity to a public park is a new location criterion complementing small school yards. The conclusion is that local governments adapt to school reforms and to compact development policies with consequences for the size and location pattern of schools. Expectations are that travel distances to schools will increase. Whereas central districts may gain from an increasing supply of schools for children aged 13-15, peripheral districts may experience a declining supply. School children are expected to be more frequent users of public parks. The implication for local governments is that school planning needs to be better integrated with strategic urban planning.

Keywords: community school, compact city, distance to school, school choice, school competition, school location, school planning, school siting, school size, Sweden.
\end{abstract}

\section{INTRODUCTION}

Many countries have adopted school reforms that give parents an extended opportunity to choose schools for their children. In the same time, it has become easier to start publicly funded, independent schools. State schools, or community schools, are expected to compete. (In Sweden, state schools are managed and owned by the local governments.) Since the introduction of these reforms in the 1990s, state schools have lost pupils; schools in the periphery of urban areas and rural schools have closed. However, the current and forecasted need for new state schools is large, especially in metropolitan regions and towns with strong population growth. This raises questions on how to organize and site new state schools.

In recent decades, urban development ideals have undergone a shift. A dominating principle for urban growth in the twentieth century was to develop suburban satellites, based on functional separation of housing, services and activities. Housing developments were organized in neighbourhood units, inspired by a model developed by Perry [1]. Lowand intermediate schools were located within these neighbourhood units. While the neighbourhood designs separated cars and pedestrians in an effort to adapt to children's abilities and needs of a safe environment, comprehensive suburban designs were adapted to the use of the car. 
The new principles for urban development are characterized by compact, high density and mixed land use, preferably in the form of city blocks with services and activities on the ground floor. At the neighbourhood level, cars and pedestrians are typically mixed in streets with pavements. These design principles are expected to lead to shorter distances to daily activities, walkability, reduced car dependency and liveable cities. However, these principles do not offer a clear direction for the siting of schools, the size or the integration of schools with housing developments.

Both school reforms and design principles imply new conditions and challenges for school planners, facility planners and town planners. The debate on schools has pointed to the fact that schools are sited in module facilities on temporary building permits and that school yards are too small to offer a stimulating environment for children. An intense debate concerns segregation effects of school choice.

The school reforms have been evaluated by Bunar [2], Holmlund et al. [3], and Böhlmark et al. [4], in terms of commuting school children, and segregation effects. The Ministry of Education [5], investigated the effects on the geographical distribution of secondary schools. Other scholars give attention to the establishment pattern of independent schools in relation to social and economic characteristics of households [6, 7]. Hellström [8] deals with the impact of school choice on local governments' forecasting and management of school facilities. Vincent [9] argues from an institutional point of view and a U.S. perspective that state schools, particularly their infrastructure and capital planning need to be much more integrated into broader urban planning and policy making. McDonald [10] examines school siting in a U.S. context, including factors influencing school facility location decisions and the role for local and regional planners in the states of Virginia and Maryland. But still, there is little evidence on how the school reforms influence the siting of schools, school size and other spatial aspects of schools in the built environment, especially in a Swedish context. Little is also known about how principles of compact and mixed land use influence school planning.

The purpose of this paper is to examine how municipalities in Sweden adapt school planning to the school reforms and to the principles of compact, high density and mixed land-use, in areas with strong population growth. The aim is to specifically examine the use of various criteria and strategies with bearing on the size and location of schools.

This paper is based on examination of strategic documents and semi-structured interviews with 17 strategic officials in five municipalities with a strong population growth and a need for many new schools. They include the three largest cities: Stockholm, Göteborg and Malmö, and two university towns: Uppsala and Linköping.

The starting point of the investigation is a number of expected criteria for the planning and location of schools. The criteria are formulated in relation to local governments' responsibilities, as competitive school organizations, as agencies responsible for providing the children with schools, and as responsible for the land use planning within the municipality. References to local governments' responsibilities are the Education Act and the Planning and Building Act. Theoretical considerations draw on location theory.

The principle results are that local governments are adapting to school competition and compact city principles by planning for much larger schools in combination with high-density developments. Schools for children aged 13-15 are sited in attractive, central locations. The official location criteria for schools of children aged 6-12 are in proximity to the local need and in consideration of younger children's limited reach. However, efficiency claims and planning practices contribute to longer distances. Whereas central districts may gain from an increasing supply of schools, peripheral districts may experience a declining supply. 


\section{SCHOOL REFORMS}

The introduction of school reforms in the 1990s gave municipalities a new role in the planning of schools. The new Education Act states that pupils should be placed in the school unit where the guardian wants the student to go. If the desired location would mean that another student's right to a placement at a school unit close to home is overridden, the municipality, however, should place the student at another school unit. When the number of pupils who want to go to a school exceeds the number of places offered by the school, the municipality must assess which pupils have the best right to a place at that school.

Parents can also apply for a place at an independent school in or outside the home municipality for their child. The general rule is that an independent school must be open to all pupils who have the right to attend primary school. Independent schools operate on much the same terms as the state primary schools. They currently receive a grant from the student's home municipality. The share of school children attending independent schools is $15 \%$, but with large variations between geographical areas [11].

\section{LOCATION CRITERIA FOR SCHOOLS}

A distinction between the proximity model and the school choice model, defined by Holmlund et al. [12], is useful in assessing location criteria. In the proximity model, pupils are referred to the school closest to home, according to the predetermined catchment areas for schools. The proximity model provides a strong connection between households' residential choice and the school that pupils attend. In the school choice model, on the other hand, the decision to choose a school is delegated to parents. Schools can adopt pupils regardless of where they live, and school funding is linked to the number of pupils who choose the respective schools. The school selection model gives households that do not have the opportunity to live near the most attractive schools, access to an attractive school in exchange for longer distance transport.

Evaluations of the school reforms in Sweden show that state schools in stigmatized neighbourhoods, in the periphery of Swedish cities, loose pupils to attractive schools in central districts [2]. Local authorities have reasons to consider these effects of competition when siting schools, both in their competitive role and in their responsibility to supply all children with a place in school.

When profit activities are introduced in a traditional non-profit sector, like school, it is expected to give incentives to the non-profit business to behave more like the profit business [6]. A study in Detroit, USA, suggests that so-called charter schools compete by location strategies. They tend to be located near the pupils who give the greatest benefit in relation to the school's aims [6]. The school's aims may be either profit or non-profit. A study in Sweden [7] shows that the probability of independent schools' establishment is clearly higher in areas with a larger proportion of residents with higher education. This paper will look into how Swedish municipalities combine their non-profit responsibilities with competition in siting schools.

The requirements of The Education Act [13] are that municipalities must consider what is efficient from the pupils' transportation point of view. Municipalities may interpret these requirements in different ways.

One reason for siting schools near homes is that proximity is important to parents. Studies in Sweden show that parents with children in lower grades highly value proximity to school relative to other properties in the residential environment [14], as well as in relation to other properties in the school [15]. 
The compact city policies including objectives related to walkability and car dependency give reasons for municipalities to consider the transportation effects of school siting. In the recent decade, there has been an academic interest in these relationships. There is evidence that the distance to school is significant in explaining children's walking and cycling to school [16].

The school selection model provides incentives for local authorities to site schools where it is possible to attract many pupils. Schools may benefit from locations where they are easily accessible for pupils from other districts. Access to high-quality public transport can be an important location factor for getting a large catchment area, especially for the older school children. High-quality public transport may also positively influence the possibilities to recruit staff to the school. Proximity to public transport hubs is particularly suitable for schools that require a large catchment area, e.g. large schools and profiled schools.

\section{METHOD}

The paper is based on examination of strategic documents and semi-structured interviews with 17 strategic officials in five municipalities with a strong population growth and a need for many new schools. They include the three largest cities; Stockholm, Göteborg and Malmö, and two university towns, Uppsala and Linköping. Linköping and Uppsala were selected among other medium-sized municipalities also on the ground that they had documented strategies for the planning of schools. Uppsala had a strategy for facility planning, and Linköping had developed guidelines for integrating schools in various urban types. The informants represent different administrative departments involved in school planning, including the departments for education, planning of facilities and town planning.

Most interviews were conducted via the phone and picture medium, Skype. Four interviews took place at the informant's workplace. Both open and closed questions were used. Examples of questions were 'Please describe the planning of schools in your municipality' 'How do you think that school reforms have affected school planning?', 'How do you think that the municipality's urban development principles have affected school planning?', 'Does the municipality have principles for school siting?' 'What is the importance of school size in your department's view?' Strategic documents included municipalities' pupil forecasts for 5-10 years and planned school investments as well as principles or guidelines for the planning of schools.

\section{RESULTS}

The result shows that local governments face major challenges in adapting school planning to school choice and competition from independent schools. It has become harder to make the pupil forecasts, and there is great uncertainty about how many places will be needed in each municipal district. The uncertainty is costly for municipalities. When they lose the student base to independent schools, they get a surplus of personnel, school places and facilities. An unplanned increase of pupils, on the other hand, often leads to costly measures.

\subsection{School size}

All five municipalities are planning for larger school units than before. Large schools are considered to reduce the vulnerability of the schools and increase facility efficiency. The argument is that schools benefit from a greater volume and that larger units increase access to teachers. In smaller school units, teachers may have to travel between the units. Large schools will also be less vulnerable to absence in the staff. Large schools are considered to be more 
efficient, specialized localities can be utilized throughout the day. But informants also believe that larger schools will offer a greater range and content of activities, which they mean will increase attractiveness.

Of importance for school size is how the school grades are organised. The facility plans show that the division and school size varies much between municipalities. Stockholm gives priority to schools with grades 0-9 (ages 6-15) and 900-1200 pupils. Also Uppsala plans for schools of that size. Göteborg plans for a broad range of schools incuding lower grade schools with 200-540 pupils, and some 0-9 grade schools with 720-840 pupils. Malmö's new schools have 500-800 pupils. Linköping has decided on schools with 600 pupils. Today, their schools are relatively small with a few hundred pupils on average.

\subsection{Sharing space}

Facility planners argue for flexibility and shared space in the school facilities. Some municipalities discuss the school as a community venue, hosting a variety of activities also during evenings, weekends and holidays. It combines the efficiency interests of the facility planners, with town planners' task to achieve the planning principles of liveable cities. Difficulties in finding land for schoolyards lead town planners to suggest that schools should be located near public parks. Proximity to a public park has become a new location criterion. This raises concerns about other users' access to parks, and concerns about parks not being adapted to the use of school children.

\subsection{Proximity criteria}

Planning processes for new school facilities start by an upcoming local need. The procedure relates to the Education Act requiring that the organisation of elementary schools should take account of what is appropriate from the transportation point of view and the right of pupils to school busing if needed. The Education Act is generally interpreted by the local administrations as a requirement of proximity between the pupil's residence and the referenced school. The requirements demand that municipalities also pay attention to school children's traffic environment.

Education administrations work with grade-related acceptance criteria of proximity. Children in the lower grades, $0-3$, or 0-6 are considered to need shorter distances to school, while children in the higher grades are considered to be able to move longer distances and to use public transportation. The previous national recommendations on quantitative distance criteria for walkability to school are outdated. Instead, municipalities use qualitative definitions of distance such as 'nearness' or 'walking distance' but without reference to how far that is.

In planning practice, planners in all municipalities use subjective assessments of nearness and walkability, indicated by statements like - 'I don't know the exact distance but we think this is okay'. Stockholm and Linköping apply a quantitative distance criterion in siting schools related to the distance where children are entitled to school busing. The intention is that no school should be sited so that the children are entitled to use school buses. Local school busing regulations specifies a maximum distance to school of two km in grades $0-3$, four $\mathrm{km}$ in grades $4-6$, and six $\mathrm{km}$ in grades $7-9$.

All the informants say that it is increasingly difficult to find places for new schools where they are needed, and that the land supply eventually rules the school location. The focus on large schools and densification developments complicates the siting, and deviations may 
therefore need to be made from the proximity criterion. In Uppsala, the municipality has to bus many children because of a lack of schools in new housing developments.

\subsection{Central location criteria}

All five municipalities adapt the siting of schools to school choice. Because of commuting surplus of pupils to the city centres, education authorities say that they must adapt the siting of schools and not build new schools in the urban periphery. This is since schools are at risk of being abandoned. Competition between schools is greater in grades 7-9 than in lower grades. Now, in all municipalities but Stockholm more schools with grades 7-9 are being built in central areas than there is a local base for. Linköping has decided on a demand oriented siting policy for schools grades 7-9, stating that schools to a larger degree will be sited with consideration of parents' preferences. Malmö has decided on a central location strategy for schools grades 7-9. The mission aims to attract pupils from all over the municipality and thereby improve social integration in schools.

\subsection{Public transport criteria}

Location criteria in relation to public transport are generally unspecific, both among school planners, facility planners and town planners. Informants say that access to public transport is important or 'extremely important', that schools should be located 'near' or 'at walking distance' from a bus stop. Yet, none of the municipalities use quantitative guidelines for the distance between the school and public transport. In Stockholm, the attitude is that the density of public transport is generally high enough and that particular ambitions for access to public transport at the schools are not required. The reasons for not siting schools at public transport nodes is that these sites often meet obstacles in the form of polluted land or noise. The environmental and health aspects are prioritized. Further reasons are that these sites are often occupied, and competition for land is higher.

Malmö, however, has adopted a traffic guideline saying that the bus stopping by the school should depart three to four times per hour between 9.00 am and $15.00 \mathrm{pm}$. Malmö's strategy to locate schools in central locations includes that schools are located close to railbound public transport. Planning is still in the outline phase, and it is not clear how the task can be performed. Informants expect difficulties with regard to land shortages, soil pollution and noise concerns. To meet the target, planners believe that it may be necessary to convert other types of facilities to school. Malmö also considers locating schools in a regional hub outside the city centre. Together, centre-oriented activities, public transport and schools are thought to increase the attractiveness of the area.

A newly planned development of the harbour area in Göteborg is ruled by an ambition to achieve the qualities of a compact, mixed use development. Schools are sited on the ground floor of the city blocks. Priority is given to walkability and public transport. The car park is located on the edge of the area to make it safer, and drivers will have to walk down to the school.

Uppsala diverges from other municipalities by applying a siting principle which adapts the siting of schools to household commuting routes by car. Schools are placed at the entrances to the new residential areas to facilitate parents' escort of children. At the same time, car traffic can be kept outside the residential areas. Schools are also located by the roads towards the centre of Uppsala where many parents have their jobs. 


\subsection{Social inclusion criteria}

Municipalities experience that school choice affects social segregation. The centrally located schools become more socially mixed due to commuting pupils from the whole municipality. This was Malmö's argument for siting schools in central locations. The consequences include that schools in the peripheral districts become more segregated, they lose resources and some schools have to close. Both socially stigmatized areas and other neighbourhoods are affected.

The extent of segregation in various municipalities and the need for action is however varying. One common measure is to redraw the geographical catchment areas for schools, so that children from different neighbourhoods mix. A method used in Linköping is to locate schools in between areas with different social characteristics in order to integrate children with different background.

An experience shared by several informants from different municipalities is that schools in richer areas are more likely to develop a mix of pupils compared to poorer areas. This is because schools in the poorer areas tend not to be selected. When there is a siting choice to make between two neighbourhoods, Stockholm will therefore choose to site new schools in the richer area.

Some education administrations are hesitant to taking measures to mix pupils from different areas. In Göteborg, the attitude is that school segregation is best solved by integrating social groups in housing developments and that this must be controlled by the urban planning process and a mix of tenures. In Uppsala, segregation problems are considered limited.

\section{DISCUSSION}

This paper shows that school competition and school choice affect the siting of schools and urban spatial development. The development principles of compact, dense and mixed land use communicate no clear direction for the school's integration with the built environment, but they create opportunities and place limits on school planning and the siting of schools.

The combination of much larger schools and high-density development is a key strategy in all municipalities. This strategy contributes to the difficulties in finding land for schools close to the homes. School yards will be smaller, and schools will be built in several stories. The concept of the compact city offers a possibility to offset the small school grounds with proximity to a public park. It raises questions about how the school children and the general public can share the park areas.

In siting schools, school planners adapt to school choice in previous years. Thus, more schools are located in central districts of cities than there is local base for, specifically school grades 7-9. The investigation does not provide evidence on the extent of this siting pattern, but the result is consistent with an observed centralisation among upper secondary schools [5]. This pattern is different from the geographical pattern found in the U.S. [9, 10]. Researchers draw a picture of larger schools located in the periphery, leading to longer trips for school children. Land-use regulations and social geographical patterns may be found behind these differences.

The primary criterion for the location of schools is to start from the local need, i.e. to site schools in proximity to children's homes. The proximity criterion is used specifically for lower grades (child aged 6-12) elementary schools. However, the proximity criterion is given lesser importance. This is a consequence of the difficulties in finding suitable land for school construction. Smaller schools may be easier to site but large schools is a higher priority than local integration. This result is consistent with the findings in a Swedish study of 11 municipalities [8], and with observations in the United States [10]. 
The proximity criterion is also overridden by the fact that school planners tend to avoid school sites where there is a high risk that the school will not be able to compete for pupils. Such sites are found in the periphery of the cities, and in socially stigmatized neighbourhoods. These priorities will have consequences for the geographical distribution of schools, in addition to the direct effects that school choice has on the schools' resources. The decline of the proximity criterion is accentuated by planners' using subjective assessments of proximity and walking distance, while former guidelines on distances to schools are outdated. For these reasons, we can expect variations in real world distances to schools. The conclusion is that municipalities adapt to competition and school choice even when the official ambition is to meet the local need.

Expectations for the future are that the decline of the proximity criterion leads to greater distances, and longer trips for school children. This in turn will provide incentives for parents to drive their children to and from school. This development contrasts to urban planning principles, which are expected to provide shorter distances and less dependence on the car. Moreover, it points to that the supply of schools will be affected by larger schools and greater distances to schools.

A starting point for the study was to assume that close access to public transport would be an essential location criterion to widen the catchment area and make schools eligible for school children from other neighbourhoods. Municipal objectives on social inclusion would also benefit from bridging the distances to schools. Moreover, public transport is an important part of the compact city concept, and to the objectives of enabling children to move around without dependence on their parents' escort. The result suggests, however, that proximity to public transport is not an important location criterion. Although the central locations are generally better-served by public transport, proximity to stations is not a high priority. Besides that, these sites are already busy or they do not meet environmental and health standards. An exception is the municipality of Malmö where administrations have been instructed to site schools, grades 7-9, close to railbound public transport. The same municipality is using the school as a strategic urban element, and as part of an urban development strategy, to guide the development to a regional hub outside the central city. Such a regional distribution of state schools may serve all districts with a choice of schools, in a better way than a further concentration to central districts would.

Expectations are high that the compact city will lead to shorter distances and reduced dependence on cars. This paper shows that the municipalities' adaptation to school reforms in combination with the compact, high-density principles, on the contrary, lead to large schools and longer distances. Moreover, while the supply of schools in central districts increases, peripheral neighbourhoods can lose schools. The overall implication for planners and decision makers is that school planning needs to be better integrated with strategic urban planning.

\section{ACKNOWLEDGEMENTS}

I want to thank the 17 respondents for providing the information necessary to write this paper. I would also like to thank my colleague, urban planner Malin Westlund, for her valuable contributions to the empirical study.

\section{REFERENCES}

[1] Perry, C.A., Housing for the Machine Age. Russel Sage Foundation, New York, 1929/1939. 
[2] Bunar, N., The geographies of education and relationships in a multicultural city: enrolling in high-poverty, low-performing, urban schools and choosing to stay there. Acta Sociologica, 53(2), pp. 141-159, 2010. Available at: www.asj.sagepub.com (accessed 9 November 2015). https://doi.org/10.1177/0001699310365732

[3] Holmlund, H., Häggblom, J., Lindahl, E., Martinson, S., Sjögren, A., Vikman, U. \& Öckert, B., Decentralisering, skolval och fristående skolor: Resultat och likvärdighet i svensk skola, Institutet för arbetsmarknads- och utbildningpolitisk utvärdering. Rapport 2014:25.

[4] Böhlmark, A., Holmlund, H. \& Lindahl, M., Skolsegregation och skolval. Institutet för arbetsmarknads- och utbildningpolitisk utvärdering. Rapport 2015:5.

[5] Skolverket, Skolmarknadens geografi: Om gymnasieelevers pendling på lokala och regionala skolmarknader, Stockholm, 2011.

[6] Gulisono, C. \& Lubienski, C., School's strategic responses to competition in segregated urban areas: patterns in school location in metropolitan detroit. Education Policy Analysis Archives, 19(13), 2011. Available at: http://epaa.asu.edu/ojs/article/view/829 (accessed 15 December 2016). https://doi.org/10.14507/epaa.v19n13.2011

[7] Angelov, N. \& Edmark, K., När skolan själv fär välja: En ESO-rapport om friskolornas etableringsmönster. Expertgruppen för studier i offentlig ekonomi. Rapport 2016:3, Wolters Kluwers, Stockholm.

[8] Hellström, A., Det fria skolvalet ur ett fastighetsperspektiv. Sveriges kommuner och landsting, 2014.

[9] Vincent, J.M., State schools as public infrastructure: roles for planning research. Journal of Planning Education and Research, 25(4), pp. 433-437, 2006. https://doi.org/10.1177/0739456x06288092

[10] Noreen C. McDonald., School siting: contested visions of the community school. Journal of the American Planning Association, 76(2), 184-198, 2010. https://doi.org/10.1080/01944361003595991

[11] Statistiska centralbyrån, Sveriges framtida befolkning 2016-2060, Statistiska meddelanden, BE 18 SM 1601. 2016.

[12] Holmlund, H., Häggblom, J., Lindahl, E., Martinson, S., Sjögren, A., Vikman, U. \& Öckert, B., Decentralisering, skolval och fristående skolor: Resultat och likvärdighet $i$ svensk skola. Institutet för arbetsmarknads- och utbildningpolitisk utvärdering. Rapport 2014:25.

[13] The Education Act, (SFS 10 kap. 29 § 2010: 800).

[14] Westford, P., Neighborhood Design and Travel: A study of Residential Quality, Child Leisure Activity and Trips to School, Doctoral Thesis, Royal Institute of Technology, Stockholm, 2010.

[15] Kairos Future, Ett val av vikt: Svenska föräldrars erfarenheter och tankar om att välja skola, juni 2014.

[16] Ewing, R., Schroeer, W. \& Greene W., School location and student travel analysis of factors affecting mode choice. Transportation Research Record: Journal of the Transportation Research Board, 1895/2004, pp. 55-63, 2007.

https://doi.org/10.3141/1895-08 